Article

\title{
Regional Geomorphological Conditions Related to Recent Changes of Glacial Lakes in the Issyk-Kul Basin, Northern Tien Shan
}

\author{
Mirlan Daiyrov ${ }^{1,2, *(1)}$, Chiyuki Narama ${ }^{3}$, Tsutomu Yamanokuchi ${ }^{4}$ (D), Takeo Tadono ${ }^{5}$, \\ Andreas Kääb ${ }^{6}$ and Jinro Ukita ${ }^{3}$ \\ 1 Graduate School of Science and Technology, Niigata University, Niigata 950-2181, Japan \\ 2 Central-Asian Institute for Applied Geosciences (CAIAG), Bishkek 720027, Kyrgyzstan \\ 3 Department of Environmental Science, Niigata University, Niigata 950-2181, Japan; \\ narama@env.sc.niigata-u.ac.jp (C.N.); jukita@env.sc.niigata-u.ac.jp (J.U.) \\ 4 Remote Sensing Technology Center of Japan (RESTEC), Tokyo 105-0001, Japan; tsutomuy@restec.or.jp \\ 5 Japan Aerospace Exploration Agency (JAXA), Tsukuba 305-8505, Japan; tadono.takeo@jaxa.jp \\ 6 Department of Geosciences, University of Oslo, 0316 Oslo, Norway; a.m.kaab@geo.uio.no \\ * Correspondence: mirlan085@gmail.com
}

Received: 24 October 2017; Accepted: 7 February 2018; Published: 14 March 2018

\begin{abstract}
To assess the current state of glacial lakes, we examine the seasonal lake-area changes of 339 glacial lakes in the Teskey and Kungoy Ranges of the Issyk-Kul Basin, Kyrgyzstan, during 2013-2016 based on optical satellite images (Landsat7/ETM+ and 8/OLI). The glacial lakes are classified into six types based on their seasonal variations in area: stable, increasing, decreasing, appearing, vanishing, and short-lived. We then track the number of each type in a given year and examine how each number changes from one year to the next. We find that many appearing, vanishing, and short-lived types occurred in both mountain ranges, having a large variability in number that is not directly related to the local short-term summer temperature anomaly, nor to precipitation or glacier recession. However, those in the Teskey Range vary significantly more than those in the Kungoy Range. To determine if the changing number and distribution of the various lake types may be due to changes in ground ice, we apply differential interferometric synthetic aperture radar (DInSAR) analysis using ALOS-2/PALSAR-2 for the debris landforms behind which glacial lakes appear. In the Teskey Range, ground ice occurs in 416 out of a total of 557 debris landforms, whereas in the Kungoy Range, ground ice occurs in 71 out of 131. In zones with predominant glacier-retreat during 1971-2010 (from Corona KH-4B and ALOS/PRISM), the Teskey Range had 180 new lake depressions as potential lake-basins, whereas the Kungoy Range had just 22. Existing depressions also expanded when melting ice produced subsidence. Such subsidence, together with debris landforms containing ground ice and ice tunnels, appear to cause the observed large number variability. In particular, the deposition of ice and debris by tunnel collapse or the freezing of storage water in a debris landform may close-off an ice tunnel, causing a lake to appear. Subsequent re-opening via melting of such blockage would produce either a vanishing or a short-lived type. In this way, the large variability in the number of each lake type and the distribution of types over this four-year period arises from regional geomorphological conditions and not directly from the local short-term summer temperature anomaly and precipitation or glacier recession.
\end{abstract}

Keywords: glacial lake; depressions; debris landform; geomorphological condition; DInSAR; Tien Shan 


\section{Introduction}

Large, sudden drainages from glacial lakes in the Central Asian mountains are an increasing threat to local populations. Although glacial lakes in this region are smaller than the more often-studied proglacial lakes in the eastern Himalayas [1-3], the resulting floods cause serious damage [4]. In the Central Asian mountains, large drainage events have occurred in three regions: northern Tien Shan in 1952-2014 [4-10], Gissar-Alay in 1977 and 1998 [11,12], and Pamirs in 2002 [13-15]. According to Popov [16], the glacial lakes here drained either through a dam incision [6,7,17-20] or through an underground ice channel inside a debris landform containing ice $[4,10,17,21]$. These drainages occur typically when a temporarily blocked underground ice channel re-opens [16]. (Here we use the more general term "debris landform containing ice" over specific names like "ice-cored moraine" because the glacial or periglacial origin and nature of the landforms are not clear and not critical to our analyses).

The Issyk-Kul Basin in northwestern Kyrgyzstan is a region with frequent disasters related to glacial lakes. In the Teskey Range, floods from the Angisay glacial lake occurred on 14 June 1974, 17 June 1975, 25 June 1980, and 14 July 1980 [6,7]. The two floods in 1980 had particularly large water volumes, but resulted in no downstream casualties. Other floods from glacial lakes in this range occurred on 7 August 1952 in Kichi-Kyzylsuu and 12 August 1964 in Tamga River [6,19]. Between 2006 and 2014, this mountain range experienced four large drainages from glacial lakes [4,10]. Here, we refer to them simply as the "short-lived type" of glacial lakes that drastically grow and drain within a few months [4,10]. For instance, on 24 July 2008, a large drainage occurred at the western Zyndan glacial lake in the northern Teskey Range [4]. This lake appeared in just two and a half months and then suddenly drained. The flood caused extensive damage, killing three people and many livestock, as well as destroying a bridge, a road, two houses, and crops. Three other large drainages also damaged a bridge, irrigation channel, roads, monuments (tomb), and agriculture fields [10]. Also, in this case the lake water drained through an ice tunnel within a debris landform containing ground ice. In the Kungoy Range, a flood from the Choktal glacial lake occurred on 27 September 1978 [6].

The recent area changes of glacial lakes are influenced by climatic conditions and glacier changes. For instance, Kapitsa and others [22] showed that the evolution of glacial lakes at the glacier front in the Djungarskiy Alatau Range is controlled by climate change, glacier melt, melt of buried ice, as well as local topography and moraine stability. Another study linked the changes of glacial lakes over the Tien Shan Mountains to climate warming and glacier shrinkages [23]. In particular, the glacier shrinkage is thought to be important for the areal expansion of glacial lakes in the northern Tien Shan $[19,24]$.

Compared to the "moraine outburst type" drainages of proglacial lakes, which occur by incision of a debris dam [22-25], few reports exist of the geomorphological conditions and mechanisms of "tunnel type" drainages of short-lived lakes through an underground channel. Is the area change of lakes with tunnel-type drainage directly related to glacier recessions or climate conditions? To help address such issues, we use here satellite-data analysis to examine the current situation of glacial lakes in the Teskey and Kungoy Ranges. Then we use this analysis plus field observations to examine their geomorphological conditions. Finally, we compare the geomorphological conditions of the two ranges.

\section{Study Area}

Our study area is the Issyk-Kul Basin, a large intermountain depression between the Teskey and Kungoy Ranges. This basin includes the northern part of the Teskey and the southern part of the Kungoy Ranges (Figure 1). The Teskey Range traverses 354 km in the E-W direction, with the highest point on Karakol (5216 m a.s.1.). The Kungoy Range traverses $285 \mathrm{~km}$ in the E-W direction, with the highest point on Chok-Tal (4770 m a.s.l.). The Teskey and Kungoy mountain ranges consist mainly of crystalline basement rocks of Archean to Middle Paleozoic age, covered by volcano-sedimentary and sedimentary strata of Devonian-Carboniferous age [26]. Along the ridge line of the eastern part of the Teskey Range, the rocks originate from granites and granitoids of the Paleozoic, whereas the 
central part has Late Ordovician granitoids and the western part has Paleozoic granitoids. Along the ridge line of the eastern part of the Kungoy Range, the rocks originate from Paleozoic granitoids and the western part is Late Ordovician granitoids [27]. Thus, the lithology around the glacial areas are essentially the same in the two mountain ranges.

The climate is continental, but due to the topography, it has much spatial variability [28]. For example, the average annual precipitation values during 1981-1990 were $594 \mathrm{~mm}$ at the Chong-Kyzylsuu station (2855 m) (data for Chong-Kyzylsuu station averaged only for 1981-1987), $297 \mathrm{~mm}$ at the Tien Shan station (3614 m), $307 \mathrm{~mm}$ at the Cholpon-Ata station (1645 m), and $625 \mathrm{~mm}$ at the Kyrchyn station $(2100 \mathrm{~m})$. See Figure 1 for locations. Over the same period, the annual average temperature was $0.2{ }^{\circ} \mathrm{C}$ at Chong-Kyzylsuu, $-7.6^{\circ} \mathrm{C}$ at Tien Shan, $8.1^{\circ} \mathrm{C}$ at Cholpon-Ata, and $2.7^{\circ} \mathrm{C}$ at Kyrchyn.

The basin region contains 834 glaciers, each with areal coverage ranging from 0.1 to $11 \mathrm{~km}^{2}$. Based on Landsat8/OLI images (2015-2016), the total glacier coverage area was $121 \mathrm{~km}^{2}$ in the northern part of the Teskey Range, but $77.1 \mathrm{~km}^{2}$ in the southern part of the Kungoy Range. Glacier areas decreased by $12 \%$ in the Kungoy Range, and 8-12\% in the Teskey Range from 1970-2000 [28-31].

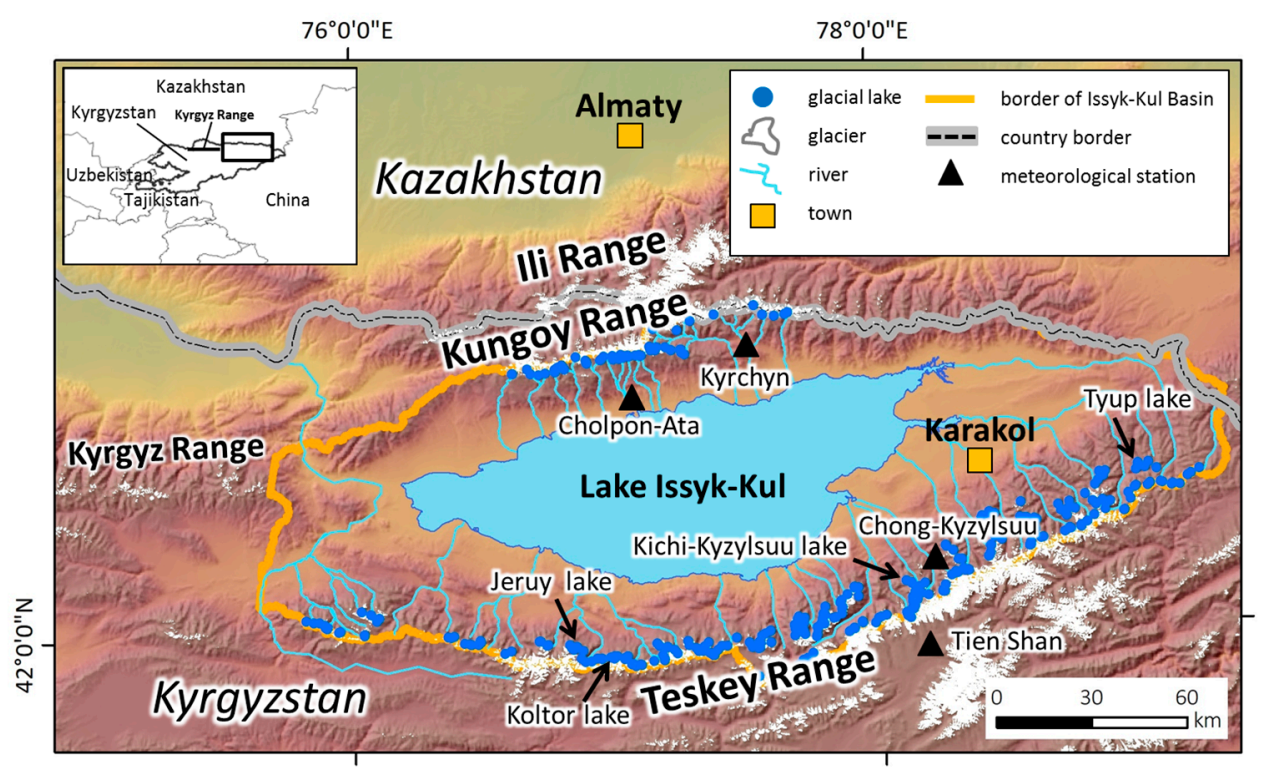

Figure 1. The Teskey and Kungoy Ranges in the Issyk-Kul Basin, Kyrgyzstan, and locations of existing glacial lakes (2016).

\section{Methods}

\subsection{Recent Variations of Glacial Lakes Using Satellite Data}

To investigate the current state of glacial lakes in the Issyk-Kul Basin, we examined the seasonal changes of the glacial-lake area using Landsat7/Enhanced Thematic Mapper Plus (ETM+, SLC-off) and Landsat8/Operational Land Imager (OLI) images (in total 128 images, 68 for Teskey, 60 for Kungoy) taken in June, July, August, September, and October during 2013-2016. Here we examine glacial lakes of area exceeding $0.0005 \mathrm{~km}^{2}$ that exist on debris landforms at glacier fronts. The glacial-lake area was delineated manually as a polygon on pan-sharpened images. To map more recent glacier coverages and their debris landforms, we use Landsat8/OLI images from 2015-2016.

We classify the glacial lakes into six types according to their seasonal change in a given year. These types are "stable", "increasing", "decreasing", "appearing", "vanishing", and "short-lived". For a given lake, we determine its type according to its change in June, July, August, September, and October of each year. "Stable" indicates that the lake area did not change seasonally from June to 
October of each year. "Increasing" means that the area increased within a season, whereas "decreasing" means a decrease in area. "Appearing" and "vanishing" types are lakes that appeared as a new lake, or disappeared due to shrinkage within a season, respectively. A "short-lived" type is a temporary lake that appeared or grew in the area, and then disappeared or shrank within the same year. A "short-lived lake" is a transient lake that experiences a sudden expansion and then, a few months later, a drainage. The short-lived type includes the "recurring" type that repeatedly appeared and disappeared at the same location during 2013-2016. Although the number of short-lived lakes is small in the study area, drainage of this type can be particularly dangerous. Examples include the Kashkasuu (2006), western Zyndan (2008), Jeruy (2013), and Karateke (2014) lakes [4,10]. For the "recurring" type, we investigate the area variations of three glacial lakes (Kichi-Kyzylsuu, Koltor, and Tyup lakes in Figure 1) in the Teskey Range during 2013-2016 using Landsat8/OLI and Sentinel-2 images. As a result, we show the number of each lake type and the distribution of lake types. When we compare the number of lakes in a given type over different years, we refer to the changes as "number variability". The "distribution" means the pattern across all lake types within one range and one year, hereafter "type variability".

We compare this year-to-year number variability and yearly type variability with the summer temperature (May-October) anomaly and precipitation during 2013-2016 at the Tien Shan and Cholpon-Ata meteorological stations (Figure 1). We use 11-day running means of summer temperature anomalies.

\subsection{Geomorphological Conditions of Glacial Lakes}

To better understand the role of the regional geomorphological conditions that cause such large number and type variabilities, we closely examine the geomorphological changes in debris landforms at Jeruy Glacier, an area that was recently the source of a large drainage event. Our method involves a digital surface model (DSM) made with input from air photos (1979) and images from an unmanned aerial vehicle (UAV) in 2016. For georeferences, the DSMs use ground-control points (GCPs) from the Advanced Land Observing Satellite/Panchromatic Remote-sensing Instrument for Stereo Mapping (ALOS/PRISM) DSM data in 2007 (Universal Transverse Mercator (UTM) 43 with World Geodetic System (WGS) 84). The DSM differences of stable areas outside of the debris landforms are $-3.7 \pm 5.8 \mathrm{~m}$ (UAV DSM minus air photo DSM). The UAV image data comes from a Phantom 4 (DJI, Shenzhen, China). These data were converted to an orthoimage and DSM using the software Pix4D mapper with GCPs. The PRISM DSMs (2.5 m resolution) were processed by Japan Aerospace Exploration Agency (JAXA) Earth Observation Research Center (EORC) as a high-level product. The standard deviations of the PRISM DSM height errors (PRISM DSM without GCPs, minus reference DSM) are between 4.9 and $8.7 \mathrm{~m}[32,33]$.

Outlines of glacial lakes, and elevation of water levels were also measured during 2008-2017 using a Global Navigation Satellite System (GNSS) survey based on Trimble GeoExplorer 6000 (cm-edition). During this same period, we observed buried ice and ice tunnels inside of some debris landforms in the field. In our region, a short-lived glacial lake appears typically in a depression on a debris landform with buried ice [4]. The existence of a depression $\left(>0.01 \mathrm{~km}^{2}\right)$ as a potential lake basin is crucial for the formation of a short-lived lake [10]. We identified such depressions $\left(>0.001 \mathrm{~km}^{2}\right)$ on debris landforms in the northern part of the Teskey Range and southern part of the Kungoy Range using a filling model based on ALOS/PRISM DSMs. The same method was also applied to other glacial lakes [10,34]. We used 14 scenes from 2007-2010 of ALOS/PRISM DSMs to determine depressions (Supplementary Table S1). We then examined the surface gradient and size of the depression. The surface gradient was calculated using the elevation (based on ALOS/PRISM DSMs) of glacier termini as derived from orthoimages, produced from Corona KH-4B (1971) and ALOS/PRISM (2007-2010) images. The Corona KH-4B data were converted to orthoimages using GCPs from ALOS/PRISM DSMs. For the GCPs, we used valley bottoms and big rocks.

According to whether or not the depression was in contact with the parent glacier, we classify it as either a depression (1) with glacier contact or (2) without glacier contact. 


\subsection{Radar Interferometry of Debris Landforms}

A short-lived lake forms typically in a depression in a debris landform with buried ice $[4,10]$. Mergili and others [35] also found that it is important to analyze the ground-ice distribution within the debris area. To understand the distribution of these debris landforms and their potential ground ice content, we first extracted areas of debris landforms at glacier fronts within ArcGIS using Landsat8/OLI and Google Earth data. Second, we ran differential interferometric SAR (DInSAR) analysis using PALSAR-2 (phased array type L-band synthetic aperture radar-2) data from the ALOS-2 satellite (Supplementary Table S2). The PALSAR-2 data came from an L-band (wavelength $23.8 \mathrm{~cm}$ ) active 1.2-GHz radar. This dataset is well-suited for long-interval DInSAR analysis such as that spanning over two years, and is not significantly influenced by the small X-band-scale (wavelength $3.1 \mathrm{~cm}$ ) vegetation cover in this region. Therefore, the PALSAR-2 enables DInSAR processing with more stable coherence than the X-band. The observation repetition of ALOS-2 is 14 days [36,37]. The complex SAR data that we used has an original resolution of $9.1 \mathrm{~m} \times 5.3 \mathrm{~m}$ (range $\times$ azimuth direction, nominal value).

We identify zones with ground ice as zones that show displacement fringes over a summer. For the Kyrgyz Range, the DInSAR data was verified using GNSS measurements [38]. Previous, and similar, applications of DInSAR include the study of motion of rock glaciers in the Swiss Alps, Sierra Nevada (USA), and Iceland [39-41]. Typically, displacement fringes on debris landforms indicate surface motion due to vertical subsidence and lateral motion. In contrast, bedrock, and grasslands or pasture areas in the valleys appear stable without any displacement. Here, the DInSAR analysis involves the GAMMA SAR software [42]. The phase of the interferogram depends on orbital parameters, such as the length of the baseline and the imaging angle, as well as surface topography and surface displacement [43]. We used image pairs with less than a 1000-m baseline. To remove the topographic phase, we used the SRTM DEM. Phase noise within the differential interferogram associated with temporal and spatial decorrelation was reduced by applying an adaptive filtering algorithm [44] implemented in the GAMMA software. We used 27 ALOS-2/PALSAR-2 images taken from 2014 to 2016 (Teskey Range: 20 images; Kungoy Range: 7 images). As a result, we defined debris landforms containing ground ice according to the existence of motion fringes in the DInSAR data.

\section{Results}

\subsection{Recent Changes of Glacial Lakes in the Issyk-Kul Basin}

In total, we investigated 339 glacial lakes and found that the number of glacial lakes of each type differed. In the Teskey Range, 31 appearing and 40 increasing lakes occurred over just 2014 through 2015 alone (Figure 2A), whereas the Kungoy Range had only five appearing and six increasing lakes over all four years (Figure 2B). For the vanishing lakes, the Teskey Range had 42 in 2013, 16 in 2014, 19 in 2015, and 30 in 2016, whereas in the Kungoy Range, these lakes numbered just 12 in 2013, 7 in 2014, 10 in 2015, and 12 in 2016. For the short-lived lakes, 56 occurred in the Teskey Range and five occurred in the Kungoy Range over all four years. Many lakes changed their type every year through 2013-2016. Although recurring short-lived types appeared at the same location, the appearing, vanishing, and short-lived types appeared both at the same and different locations.

The type variability also differed between the two ranges. For example, in the Teskey Range, the year 2013 had a high proportion of decreasing (46 of 71) and vanishing lakes (42 of 107), but years 2014 and 2015 instead had a high proportion of appearing (31 of 51) and increasing (40 of 53) lakes, with a slightly higher percentage of these types in 2015 (Figure 2A). Although 2016 had only three increasing lakes, it had 22 short-lived cases, which is a higher percentage of this type compared to other years.

Compared to the Teskey Range, the Kungoy Range had a higher proportion of vanishing lakes in all four years (Figure 2B). Also, unlike the Teskey Range, the Kungoy Range had years without any increasing and years without any decreasing types. In contrast to the other types, these increasing and decreasing types are closely related to glacier variations. For example, a lake shrinks when the glacier 
separates from the lake due to glacier recession. When a glacial lake continues to have contact with the glacier under recession, the lake expands gradually. Four appearing lakes occur in 2014 and only one in 2016, whereas vanishing lakes total 41 through all four years. Of the short-lived lakes, four occur in 2013 and one in 2015. Over all four years, the total number of these other three types exceeds the total number of increasing and decreasing types.
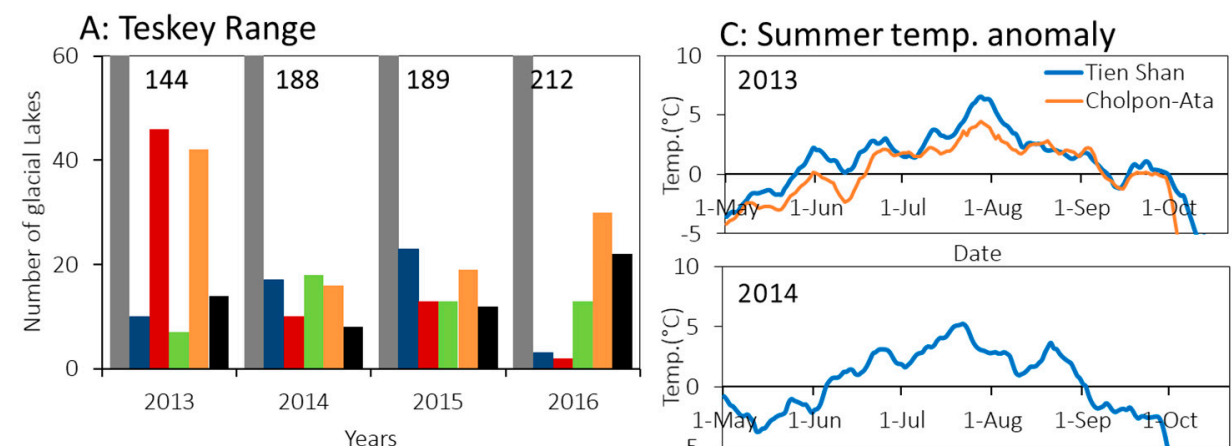

B: Kungoy Range
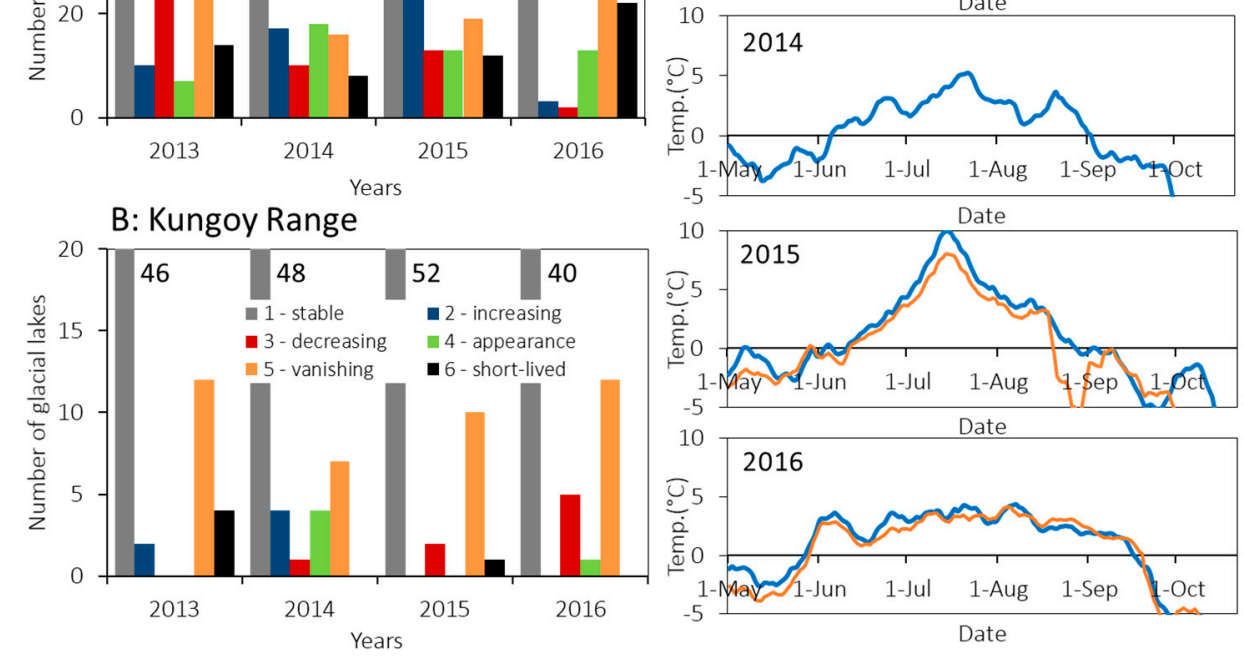

Figure 2. Number of lakes in the six types and the summer temperature anomaly in the Issyk-Kul Basin during 2013-2016. (A) Teskey Range. (B) Kungoy Range. The value next to the grey bar shows the number of "stable" lakes. (C) Eleven-day running means of summer temperature (May-October) anomaly during 2013-2016 at the Tien Shan (Teskey Range) and Cholpon-Ata (Kungoy Range) meteorological stations (for locations, see Figure 1). For these six months, the average temperatures of the Tien Shan meteorological station were $2.4^{\circ} \mathrm{C}$ in $2013,1.5^{\circ} \mathrm{C}$ in $2014,2.5^{\circ} \mathrm{C}$ in 2015 , and $2.1^{\circ} \mathrm{C}$ in 2016, whereas those for the Cholpon-Ata meteorological station were $15.8^{\circ} \mathrm{C}$ in $2013,15.5^{\circ} \mathrm{C}$ in 2015 , and $15.3^{\circ} \mathrm{C}$ in 2016 .

For these lake types, how do the number and type variabilities depend on summer temperature (May-October)? For the years 2013-2016, both the Tien Shan and Cholpon-Ata meteorological stations had similar trends of temperature anomalies, defined as temperature difference from the average over all 24 months (Figure 2C). Although the summer temperature anomaly in 2013 was comparable or lower than that in 2015, the distribution of types is more uniform in 2015 in the Teskey Range. In addition, the Teskey Range has many decreasing lakes when the summer temperature is average in 2013, whereas the Kungoy Range has none decreasing. Compared to 2014 and 2015, the type variability in the Teskey Range is about the same even though the summer temperature in 2015 is higher than that in 2014. In contrast, the type variability in the Kungoy Range is different in these years.

Also, despite both ranges having higher-than-average summer precipitation in both 2013 and 2015 (compared to 2014 and 2016, not shown here), the number of increasing lake type is relatively high only in the Teskey Range in 2015, whereas the number of decreasing lake type is relatively high in 2013. The numbers of appearing lakes show no clear trend with year. The same holds for the other types. Moreover, the distribution of lake types is not consistent from year to year. Thus, the results show that the large number and type variabilities over this short period are not directly related to the local short-term summer temperature anomaly, the precipitation, and the glacier recession. 
The short-lived lake type, though much less common than the other types, is nevertheless significant. This type occurred 56 times in the Teskey Range over all four years versus just five in the Kungoy Range. In the Teskey Range, they occurred every year, with 22 such lakes observed in 2016. Using Landsat8/OLI and Sentinel-2 images, we also identified three lakes of recurring type (for location see Figure 1) among these short-lived lakes from 2013 and 2016 (Figure 3A). This type changes size and shape every year. See Figure 3B for examples of the annual areal variations of the Koltor lake. The area changes of three lakes (Figure 3) also do not directly correlate with temperature variation. Lakes of the recurring type have different variations (timing and area) each year.

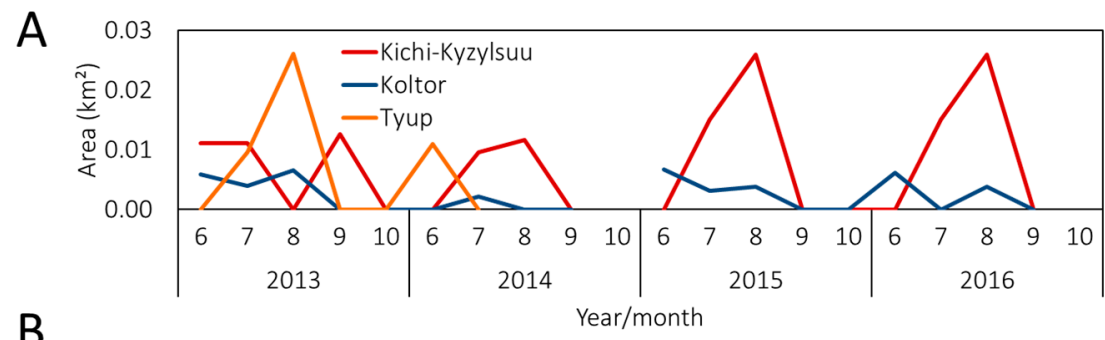

B

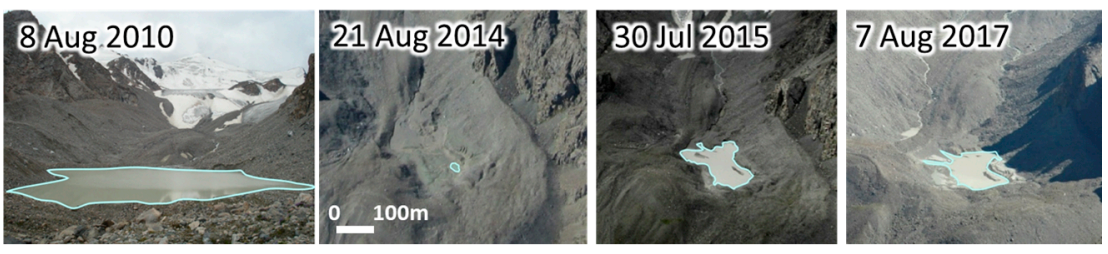

Figure 3. Recurring-type of short-lived lakes in the Teskey Range. (A) Inter-annual areal variations of the Kichi-Kyzylsuu, Koltor, and Tyup lakes (for locations, see Figure 1) between 2013 and 2016. (B) Images of the Koltor lake in 2010 (photo from fieldwork by authors), 2014, 2015, and 2017 (photos from helicopter by authors) with the boundaries highlighted.

\subsection{Recent Surface Changes of Debris Landform at Jeruy Glacier Front}

To consider another possible cause of the large variability in the number of each type and the distribution of types, we investigated the geomorphological conditions in the study area. First, we examined the surface changes of debris landforms at Jeruy Glacier front, as one of the short-lived type lakes, from 1979 (airphoto) through 2016 (UAV image). The debris landforms have no clear moraine ridges in either year. Between air photo and UAV images, several landforms have changed (Figure 4): many small ridges appeared on the debris landform, a depression on the left bank of the glacier front became unclear, the glacier terminus retreated by $150 \mathrm{~m}$, a large depression formed where the glacier retreated. (A short-lived glacial lake appeared there and caused a large drainage on 15 August 2013 [10].) Also, an outlet channel expanded, with a longer section of exposed ice and small kettles (sinkholes) formed around the channel. We also observed much ice and an ice tunnel at some exposed parts in 2014.

Considering the profiles of the debris landform at the Jeruy Glacier front from 1979 to 2016, it can be seen that overall, the surface elevation steadily declined, with the depression expanding and lowering by up to $20 \mathrm{~m}$ at the glacier front (Figure $5 \mathrm{~A}$ ). The channel cleared by down-wasting and thawing as shown on the longitudinal profile along a-a' (Figure 5A) and on the transverse profile of the lake dam along $\mathrm{b}-\mathrm{b}^{\prime}$ (Figure $5 \mathrm{~B}$ ). 


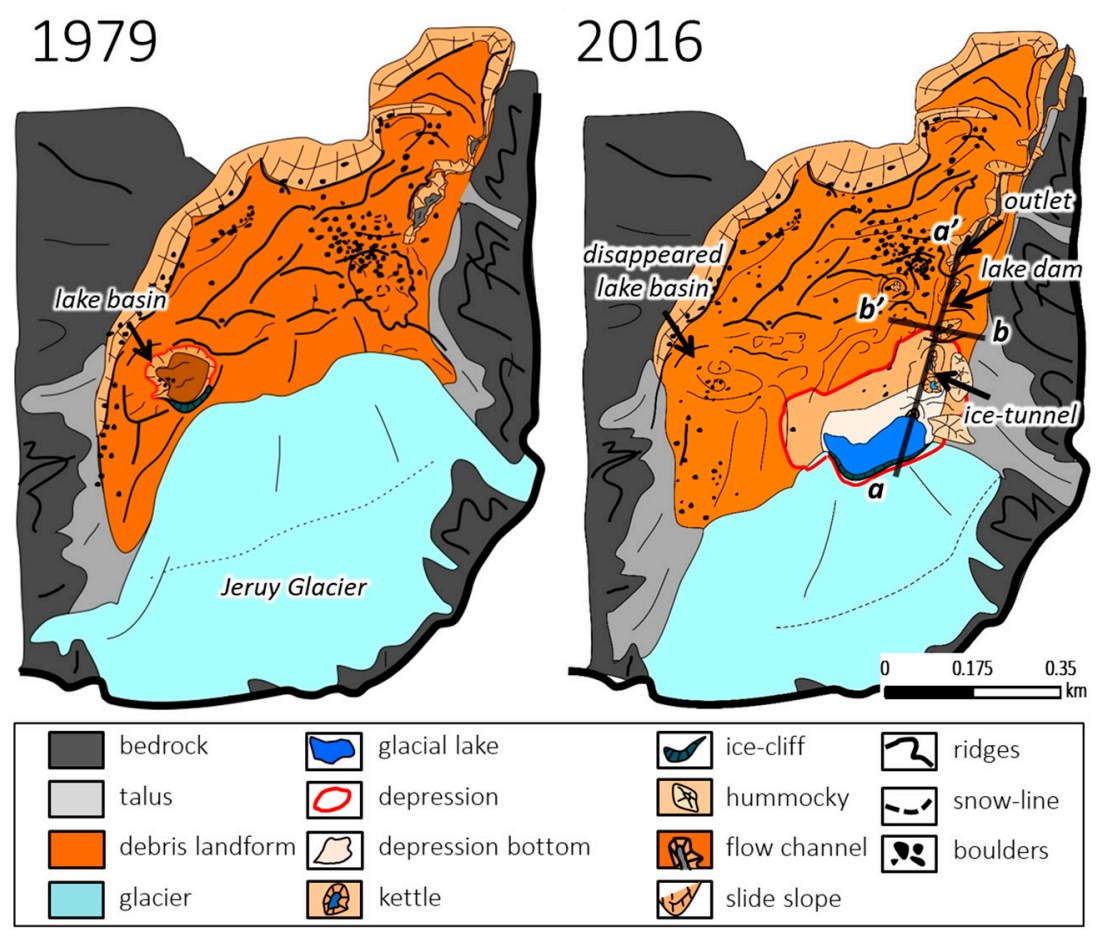

Figure 4. Surface changes of the debris landform at Jeruy Glacier between 1979 and 2016. Data based on orthoimages from air photos (1979) and digital images taken by a UAV (2016).
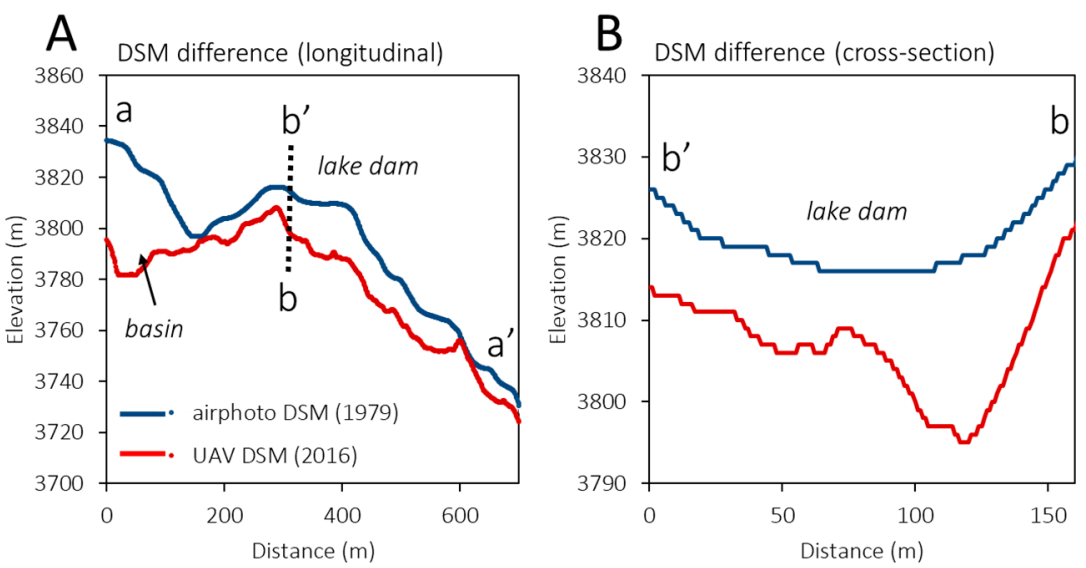

Figure 5. Elevation profiles from 1979 and 2016 of debris landforms at the Jeruy Glacier. (A) Longitudinal profile along a-a' marked in the 2016 panel of Figure 4. (B) Transverse profile along b-b' from the same panel. Based on DSMs generated from air photos (1979) and UAV images (2016).

\subsection{Analysis of Depressions on Debris Landforms}

Using ALOS/PRISM DSMs (2007-2010), we identified a total of 372 depressions $\left(>0.001 \mathrm{~km}^{2}\right)$, with 328 in the Teskey Range and 44 in the Kungoy Range. By comparing them to glacier positions in 1971, we determined that 202 of the 372 had appeared due to glacier recession between 1971 and 2007-2010. Of these, 180 (of 328 in total) were in the Teskey Range and the remaining 22 (of 44 in total) in the Kungoy Range. Although the distributions of depression area by area class are roughly the same in both ranges (particularly for those without glacier contact), the Teskey Range hosts many more depressions than the Kungoy Range (Figure 6A). Another difference between the two ranges is that in the Teskey Range, nearly half (45\%) of the depressions are of the glacier-contact type, whereas in the Kungoy Range, nearly all ( $80 \%)$ are of the type without glacier contact (Figure 6A). This difference is 
a result of the glacier shrinkage being larger in the Kungoy Range. Among all the depressions, 45 had existing lakes, but most of them were less than $0.01 \mathrm{~km}^{2}$, with the Teskey Range having only 13 larger lakes and the Kungoy Range having no larger lakes.
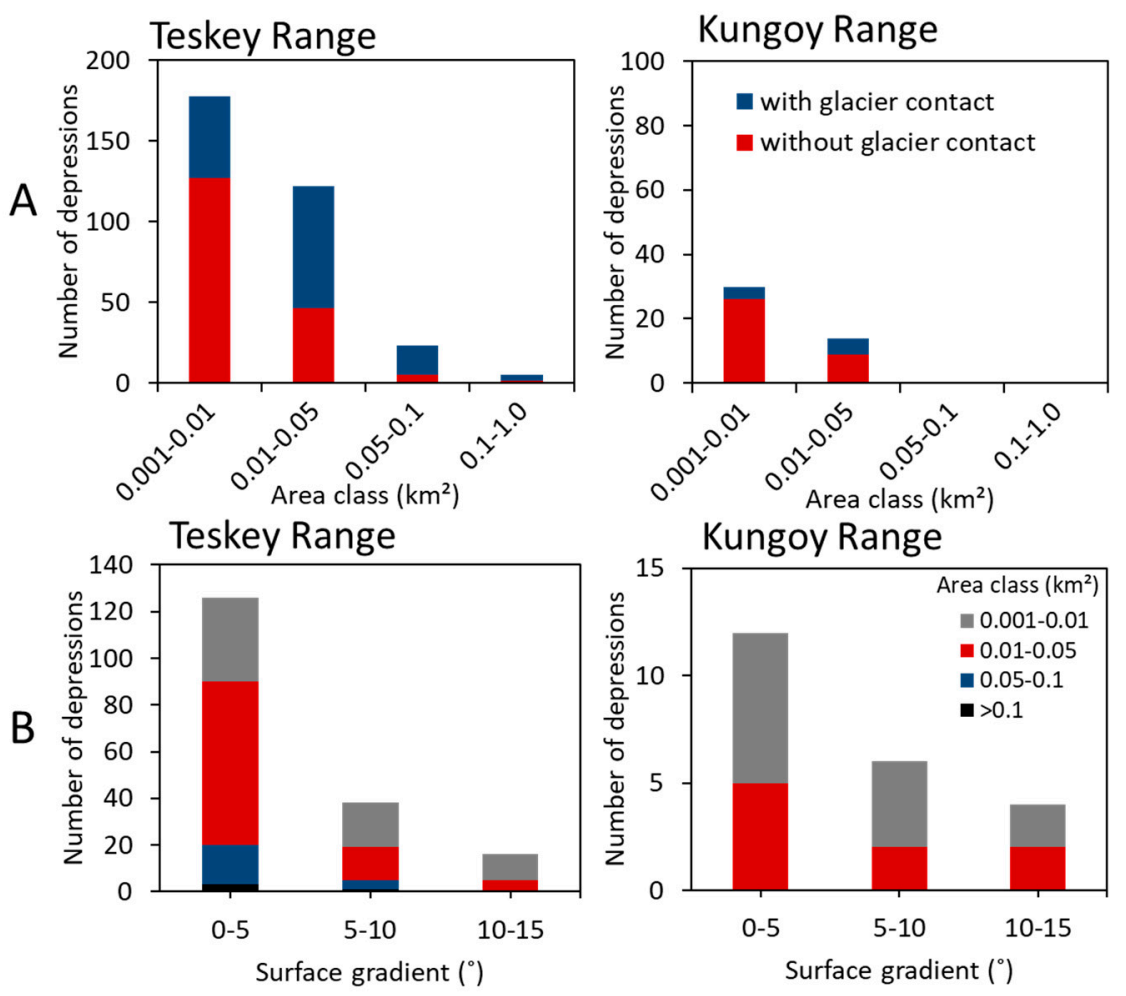

Figure 6. Characteristics of depressions in the Teskey and Kungoy Ranges. (A) The number of depressions with and without glacier contact of the various area classes. (B) The number of depressions of various surface-gradient ranges for each area class.

We consider now the surface gradient at all glacier termini at which depressions appeared between 1971 and 2007-2010. In general, the smaller the gradient, the greater the number of depressions, with no depressions found on slopes of $15^{\circ}$ or more (Figure 6B). Although all three surface-gradient bins include depression areas, the smaller surface gradients have more depressions. In the Teskey Range, many depressions occur on slopes less than $5^{\circ}$, including larger size depressions $\left(>0.05 \mathrm{~km}^{2}\right)$. In the Kungoy Range, none of these larger depressions occur on slopes within $15^{\circ}$. Thus, the formation of depressions seems related to (i) the surface changes from melting ice on the debris landforms; (ii) the glacier shrinkage; and (iii) the glacier termini slope.

\subsection{Distribution of Debris Landforms with Ground Ice}

Ground ice occurrences were estimated using DInSAR images of the Jeruy Glacier front based on one-year interferograms between 4 October 2015 and 30 October 2016 (Figure 7A). The results show the displacement fringes on the debris landform. A displacement fringe indicates surface motion, which in turn, indicates ground ice. The stable regions (same color, no fringes) showing no motion are outside the debris landform area. These regions are riverbed, talus landform, and bedrock areas. The steep slope area at right-bank of the debris landform is labeled as the foreshortening part of the DInSAR images. The motion area seems mainly influenced by the melting of ground ice and subsequent subsidence as suggested by the vertical surface decline shown in Figure 5. Lateral movement due to gravity-driven deformation might also be occurring in the motion area. 

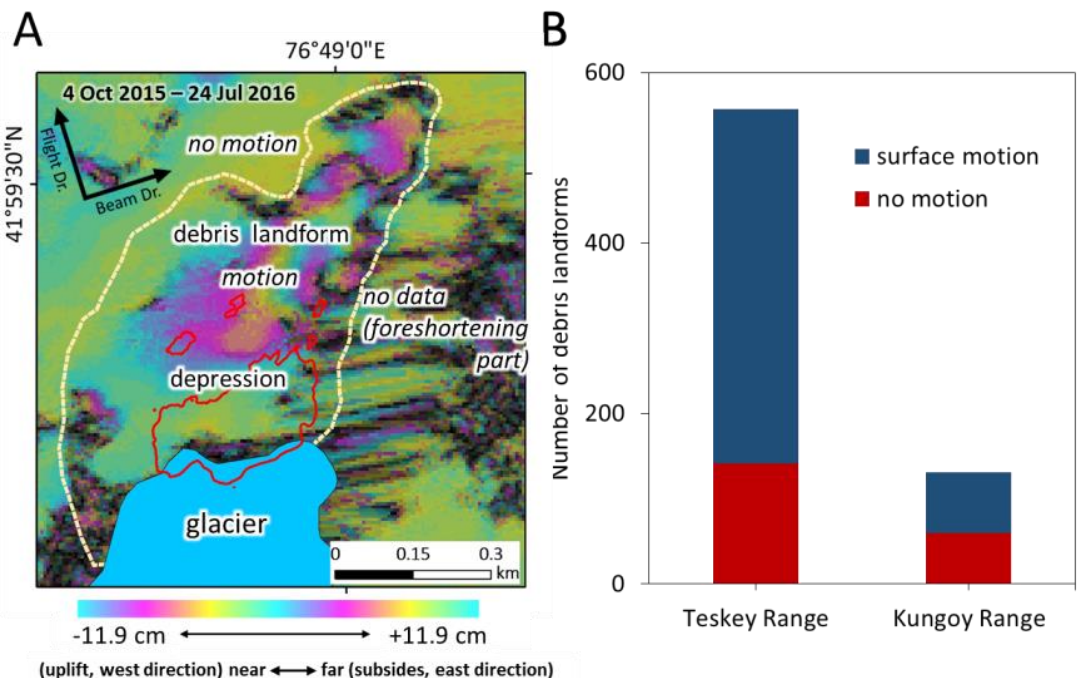

Figure 7. Surface motion around the Jeruy Glacier front. (A) Surface displacement map by DInSAR analysis using ALOS-2/PALSAR-2 data. (B) The resulting number of debris landforms with and without ground ice (or only little ground ice without significant effect on surface deformation) over the study region.

Using one-year pairs and short-period pairs between 2014 and 2016 (ALOS-2/PALSAR-2), we analyzed a total of 688 debris landforms (Teskey Range: 557; Kungoy Range: 131) at glacier termini that show displacement fringes (Figure 7B). Among them, the area class of $0.1-1.0 \mathrm{~km}^{2}$ of debris landforms accounted for $83 \%$ of the total in the Teskey and $81 \%$ in the Kungoy Range. Overall, most of the debris landforms at glacier fronts have this indication of ground ice; specifically, 416 of 557 in the Teskey Range and 71 of 131 in the Kungoy Range.

\section{Discussion}

\subsection{Regional Geomorphological Conditions of the Glacial Lakes in the Issyk-Kul Basin}

Previous studies [22-24] stated that expansion of glacial lakes in the Djungarskiy Alatau Range and Tien Shan Mountains is related to climatic variations and glacier recession. Although an overall increase in lake area is influenced by glacial recession and climate changes over a decades-long time-scale, our data shows that every year has large number and type variabilities. These seasonal and annual variations in the Teskey and Kungoy Ranges do not directly coincide with variations in summer temperature anomaly and precipitation, and the number of each type and the distribution of types also differ between the mountain ranges (Figure 2). Instead, the main reason for the occurrence of the large year-to-year variability in number and type appears to be local geomorphological conditions. These conditions include the existence of debris landforms containing ground ice and the formation and development of depressions.

An important influence on glacial lakes in the study region is their drainage through ice tunnels and ice dams. For example, Narama and others $[4,10]$ reported that ice-tunnel drainage channels of four large drainages (2006-2014) close during winter and then open again in summer. They showed that this closure occurs by either freezing or by debris/ice deposition via channel collapse. Also, Mergili and others [35] pointed out that the behavior of glacial lakes in the region depends on whether the dam contains ice. In addition, other environmental factors affect these glacial lakes. For example, as shown for the Jeruy Glacier front (Figure 4), substantial down-wasting of debris landforms with buried ice causes surface changes. The subsidence and down-wasting of the debris landform changes how a depression forms and changes the ice-tunnel conditions inside of the landform. These surface 
changes might lead to the blockage and closure of ice tunnels due to deposition of ice and debris by tunnel collapse.

Degradation of a debris-covered glacier also causes large surface subsidence [44]. For example, ground ice melting by thermokarst processes leads to the development of various landforms [45]. Also, thermal erosion by lake water might enlarge a lake basin [46]. In the Issyk-Kul Basin, these regional cryospheric conditions cause the observed large year-to-year variability in number and type (Figure 2). In short, the large number and type variabilities are due to regional geomorphological conditions involving the existence of debris landforms containing ground ice, the formation of depressions resulting from glacier recession, vertical subsidence on debris landforms, and surface changes of debris landforms due to ice melting. In addition, surface changes or the freezing of storage water might lead to the closure of an ice tunnel inside a debris landform due to the deposition of ice and debris by tunnel collapse. As a result of geomorphological conditions, tunnel closure and opening cause the observed appearing, vanishing, and short-lived lakes.

However, over decades-long periods, climate change and glacier recession affect the lake extension of stable or increasing lakes. Also, although the appearance of glacial lakes may be linked to climate and glacier recession, some of these lakes change to another type. In addition, the short-lived lake type occurs 56 times in the Teskey Range over all four years versus just five times in the Kungoy Range. However, only two large drainages occurred from the Jeruy (2013) and Karateke (2014) glacial lakes during 2013-2016. These large drainages might be influenced by the tunnel conditions.

\subsection{Differences of Regional Geomorphological Conditions between the Teskey and Kungoy Ranges}

Over the past decade, some large drainages have occurred from short-lived glacial lakes in the Teskey Range, but not the Kungoy Range. In the Kungoy Range, the most recent flood occurred from Choktal glacial lake on 27 September 1978, which drained through a dam incision [6]. As a possible explanation for this difference between the two ranges, we will now describe differences between their regional geomorphological conditions.

Along the ridge line of both ranges, the rocks have similar origins, originating mainly from granites of the Paleozoic and Ordovician. In the eastern part of the Teskey Range, the rocks of the debris landforms partly originate from Paleozoic and Proterozoic gneisses and marbles. However, lake variability in the numbers of each type and their distributions are large in the same lithological area. This means that the rock types do not significantly influence either kind of lake variability.

Concerning the local short-term summer temperature anomaly and precipitation, both ranges have a similar summer temperature anomaly. Large year-to-year variability in their number and type occurred every year in both ranges. Thus, we argue that such lake variability over this short period (1-4 years) is instead strongly related to local geomorphological conditions, and is not directly influenced by the local short-term summer temperature anomaly and precipitation or glacier recession.

Consider the elevation ranges. Figure $8 \mathrm{~A}$ shows the Teskey Range with glacial lakes at an elevation range of $3200-4100 \mathrm{~m}$ a.s.l. and debris landforms containing ice at $3200-4000 \mathrm{~m}$ a.s.l., giving an 800-m-elevation overlap between these geomorphic forms. For the Kungoy Range, the lakes occur at 3400-3900 $\mathrm{m}$ a.s.l. and the debris landforms with ice at 3100-3700 $\mathrm{m}$ a.s.l., giving a much smaller 300-m-elevation overlap (Figure 8B). The differences in altitudinal overlap reflect the differences of environmental condition such as climate and landform. In addition, the differences in the overlap also reflect the differences in the number of glacial lakes and depressions, which in turn are influenced by the debris landforms containing ice. The number of debris landforms with ice also differ, being 416 in the Teskey Range and 71 in the Kungoy Range. Thus, in the Teskey Range, the glacial lakes (depressions) form at the same elevations as the debris landforms with ice, whereas in the Kungoy Range, the glacial lakes have higher elevations than the debris landforms with ice. 

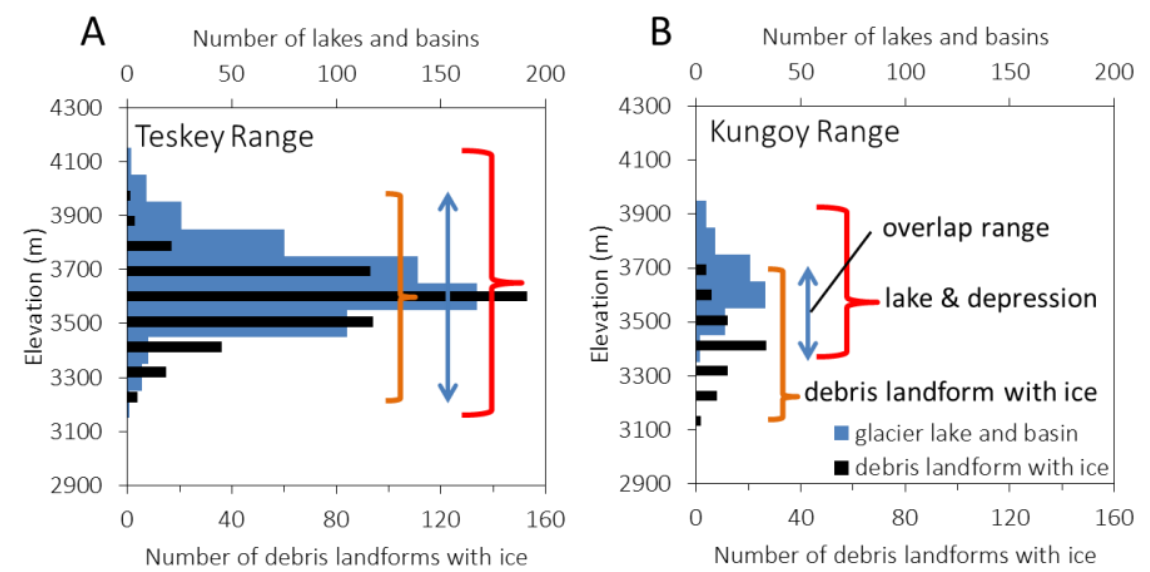

Figure 8. Elevation ranges for the zones of glacial lake depressions and debris landforms with buried ice in the Teskey (A) and Kungoy (B) Ranges.

In addition, the number of debris landforms (black bar in Figure 8) at each overlap-range elevation is larger in the Teskey Range than in the Kungoy Range (93 vs. 4 at 3700 m and 153 vs. 6 at 3600 m). This shows that the Teskey Range has many places in which appearing, vanishing and short-lived lakes can occur. In fact, the number of appearing and short-lived lakes is quite large in the Teskey Range. This shows that the Teskey Range has favorable conditions for ice-tunnel closure.

The glacier shrinkage in both ranges influences the conditions of the depressions. Due to the smaller glacier shrinkage in the Teskey Range, a larger fraction of the depressions have contact with the parent glacier than that in the Kungoy Range (Figure 6A). Specifically, in the Teskey Range, 37\% of all depressions are the glacier-contact type, but of just the middle-sized depressions $\left(0.01-0.1 \mathrm{~km}^{2}\right)$, $60 \%$ are of the glacier-contact type. However, in the Kungoy Range, due to the greater glacial shrinkage, most depressions are separated from glacier termini. Contact with the glacier may be important for the formation of short-lived glacial lakes. In particular, we found that recent new depressions with glacier contact have a high probability of forming a short-lived glacial lake because such depressions have an inflow channel from the glacier and thus water supply to form lakes. In contrast, the behavior of depressions without glacier contact depends on the connection to meltwater channels from the glacier [10]. But despite the relatively large amount of glacier shrinkage in the Kungoy Range, this range has a relatively small number of the increasing type.

Looking at other cases, Emmer and others [47] reported that proglacial lakes (i.e., glacier-contact type) turn to a glacier-detached phase (i.e., without glacier-contact type) in the Andes Mountains. The different scale of glacier shrinkage influences the formation or extension of depressions in our study region. For example, in the Teskey Range, a small glacier recession leads to an extension of the depression with glacier contact, whereas a large recession causes many separations between depressions and a larger separation from the glacier. As a result, and consistent with our findings, the Teskey Range has geomorphological conditions that are more favorable for depressions.

Thus, compared to the Kungoy Range, the Teskey Range has (1) more debris landforms with buried ice that developed along glacier fronts; (2) more large depressions with glacier contact that appeared within the past 40 years where a glacier retreated slowly; and (3) an elevation range of glacial lakes that coincides more with that of the debris landforms with buried ice. Although Narama and others [10] pointed out the geomorphological characteristics in which short-lived lakes appear, the present study stresses the distribution of geomorphological condition in the Issyk-Kul Basin, and the importance of differences in geomorphological conditions on regional scales between the Teskey and Kungoy Ranges.

As a result, the regional glacier and geomorphological changes found here impact lake variability in both number and distribution. In particular, the geomorphological changes over a short period (1-4 years) may change tunnel conditions and depression formation. These regional special conditions 
may induce short-lived lake appearances due to glacier/debris/ice instability. Thus, short-lived lakes that cause large drainages should be closely monitored.

\section{Conclusions}

For the Teskey and Kungoy Ranges of the Issyk-Kul Basin, we described the seasonal area changes of 339 glacial lakes. These lakes were classified into six types with respect to area changes: stable, increasing, decreasing, appearing, vanishing, and short-lived. Lakes in the Teskey Range varied by number and type significantly more than those in the Kungoy Range. In the Teskey Range, 31 appearing and 40 increasing lakes occurred in just 2014 and 2015, whereas only five appearing and six increasing lakes in the Kungoy Range were identified over four years. For the vanishing lakes, the Teskey Range had $42,16,19$, and 30 in each of the four years, respectively, whereas the Kungoy Range had just 12, 7, 10, and 12. For the short-lived lakes, the Teskey Range had 56 over the four years, whereas the Kungoy Range had just five. The large year-to-year variabilities in both number and distribution were not directly related to local short-term summer temperature anomaly, nor to precipitation or glacier recession during 2013-2016.

We investigated the regional geomorphological conditions that caused these large number and type variabilities using field observation and satellite data analysis. We argued that these variations arise from regional geomorphological conditions involving the existence of debris landforms containing ground ice, the formation of depressions resulting from glacier recession, vertical subsidence on debris landforms, and surface changes of debris landforms due to melting of the ice content. In addition, surface changes or the freezing of storage water might lead to the closure of an ice tunnel inside a debris landform due to the deposition of ice and debris by tunnel collapse. Three types of appearing, vanishing, and short-lived lakes (including recurring ones) are related to these regional geomorphological conditions, and not directly related to the local short-term summer temperature anomaly, the precipitation, and glacier recession.

Compared to the Kungoy Range, the Teskey Range has recent large drainage events. This latter range has glacial lakes/depressions occurring at the same elevations as debris landforms containing ground ice, a condition leading to a large ratio of depressions with glacier contact as well as a large number of depressions and debris landforms containing ground ice. These forms and conditions are more conducive to appearing, vanishing, and short-lived lakes, which we suggest explains the greater number observed in the region.

Supplementary Materials: The following are available online at http://www.mdpi.com/2076-3263/8/3/99/s1, Table S1: ALOS/PRISM data (2007-2010) for determining depressions and calculating slopes, Table S2: ALOS-2/PALSAR-2 data (2014-2016) used to extract debris landforms with ground ice by DInSAR analysis.

Acknowledgments: Special thanks are due to B. Moldobekov, S. Usupbaev, A. Osmonov of Central-Asian Institute for Applied Geosciences (CAIAG), A. Aitaliev of the Ministry of Emergency Situations of the Kyrgyz Republic, S. Yerokhin of Geology Institute of the Kyrgyz Republic, K. Abdrakhmatov of Institute of Seismology, Y. Mori and H. Takadama of Niigata University for support of our research. We also thank a main editor U. Kamp, an assistant editor L. Zheng, and three anonymous reviewers for valuable comments. This study was supported by Japanese Government (Monbukagakusho: MEXT) Scholarships at Graduate School of Science and Technology, Niigata University in 2015-2017, SASAGAWA Foundation of Japan in 2016, the Mitsui \& Co. Environmental Fund in 2013-2015 and Grant-in-Aid for Scientific Research (C) 25350422 and (B) 16H05642 of the Ministry of Education, and Culture, Sports, Science and Technology (MEXT). This study used ALOS satellite image data from ALOS Research Announcement (RA) in the framework of JAXA EORC. A. Kääb acknowledges support by the European Research Council under the European Union's Seventh Framework Programme (FP/2007-2013)/ERC grant agreement No. 320816, and the European Space Agency (ESA) within the Glacier_CCI (code 400010177810IAM) and DUE GlobPermafrost projects (4000116196/15/IN-B). This work is also a contribution to the SIU CryoJaNo project (HNP-2015/10010). 15/10010).

Author Contributions: Mirlan Daiyrov and Chiyuki Narama conducted field survey. Mirlan Daiyrov performed an analysis of field and satellite data. Tsutomu Yamanokuchi and Takeo Tadono supported DInSAR analysis with ALOS-2/PALSAR-2 data. Andreas Kääb and Jinro Ukita checked the manuscript and suggested some discussion points. Mirlan Daiyrov wrote the paper and Chiyuki Narama improved the manuscript. 
Conflicts of Interest: The authors declare no conflict of interest. The funding sponsors had no role in the design of the study; in the collection, analyses, or interpretation of data; in the writing of the manuscript, and in the decision to publish the results.

\section{References}

1. Ageta, Y.; Iwata, S.; Yabuki, H.; Naito, N.; Sakai, A.; Narama, C.; Karma. Expansion of Glacier Lakes in Recent Decades in the Bhutan Himalayas; IAHS Publication: Wallingford, UK, 2000; pp. 165-175.

2. Komori, J.; Gurung, D.R.; Iwata, S.; Yabuki, H. Variation and lake expansion of Chubda Glacier, Bhutan Himalayas, during the last 35 years. Bull. Glaciol. Res. 2004, 21, 49-55.

3. Bajracharya, S.R.; Mool, P.K.; Shrestha, B.R. Impact of Climate Change on Himalayan Glaciers and Glacial Lakes: Case Studies on GLOF and Associated Hazards in Nepal and Bhutan; ICIMOD: Kathmandu, Nepal, 2007.

4. Narama, C.; Duishonakunov, M.; Kääb, A.; Daiyrov, M.; Abdrakhmatov, K. The 24 July 2008 outburst flood at the western Zyndan glacier lake and recent regional changes in glacier lakes of the Teskey Ala-Too range, Tien Shan, Kyrgyzstan. Nat. Hazards Earth Syst. Sci. 2010a, 10, 647-659. [CrossRef]

5. Baimoldaev, T.; Vinohodov, B. Kazselezaschita-Safety Measures before and after the Disasters; National Academy of Sciences of the Republic of Kazakhstan: Almaty, Kazakhstan, 2007. (In Russian)

6. Kubrushko, S.S.; Shatravin, V.I. Long-term prediction of glacial mudflows in Tien Shan. Data Glaciol. Stud. 1982, 43, 60-62. (In Russian)

7. Kubrushko, S.S.; Staviskiy, Y.S. Glacier lakes of Kyrgyzstan and their role in mudflow formation. Data Glaciol. Stud. 1978, 32, 59-62. (In Russian)

8. Janský, B.; Šobr, M.; Engel, Z. Outburst flood hazard: Case studies from the Tien-Shan Mountains, Kyrgyzstan. Limnol.-Ecol. Manag. Inland Waters 2010, 40, 358-364. [CrossRef]

9. Narama, C.; Severskiy, I.; Yegorov, A. Current state of glacier changes, glacial lakes, and outburst floods in the Ile Ala-Tau and Kungöy Ala-Too ranges, northern Tien Shan Mountains. Geogr. Stud. 2009, 84, 22-32. [CrossRef]

10. Narama, C.; Daiyrov, M.; Duishonakunov, M.; Tadono, T.; Hayato, S.; Kääb, A.; Ukita, J.; Abdrakhmatov, K. Large drainage from short-lived glacial lakes in the Teskey Range, Tien Shan Mountains, Central Asia. Nat. Hazards Earth Syst. Sci. 2018, 18. [CrossRef]

11. Nikitin, A.M.; Shchetinnikov, A.C. Mudflows in the Isfairamsai River-Basin in 1977. Data Glaciol. Stud. 1980, 39, 107-110. (In Russian)

12. UNEP. Global Outlook for Ice and Snow; UNEP: Nairobi, Kenya, 2007.

13. Mergili, M.; Kopf, C.; Müllebner, B.; Schneider, J.F. Changes of the cryosphere and related geohazards in the high-mountain areas of Tajikistan and Austria: A comparison. Geogr. Ann. Ser. A Phys. Geogr. 2012, 93, 79-96. [CrossRef]

14. Mergili, M.; Schneider, J.F. Regional-scale analysis of lake outburst hazard in the southwestern Pamir, Tajikistan, based on remote sensing and GIS. Nat. Hazards Earth Syst. Sci. 2011, 11, 1447-1462. [CrossRef]

15. Mergili, M.; Schneider, J.F.; Worni, R.; Schneider, J.F. Glacial lake outburst floods in the Pamir of Tajikistan: Challenges in prediction and modelling. In Proceedings of the 5th International Conference on Debris-Flow Hazards: Mitigation, Mechanics, Prediction and Assessment, Padua, Italy, 14-17 June 2011.

16. Popov, N.V. Outburst glacial mudflows and their prevention in the mountains of Northern Tien Shan. Data Glaciol. Stud. 1987, 59, 188-193. (In Russian)

17. Tokmagambetov, G.A.; Sudakov, P.A.; Plekhanov, P.A. Periglacial lakes in Zailiysky Alatau (Ile Range), Northern Tien Shan Mountains. Data Glaciol. Stud. 1980, 39, 97-101. (In Russian)

18. Shatravin, V.I. Origin and structure of glacial lakes in Kyrgyzstan and mechanism of their outbursts. Trudy Kazn. Debris-Flows 1984, 8,77-83. (In Russian)

19. Erokhin, S. Data report of glacial lakes in 2000-2008. In Inventory of Glacial Lakes; Ministry of Emergency Situations of the Kyrgyz Republic: Bishkek, Kyrgyzstan, 2008. (In Russian)

20. Janský, B.; Cerný, M.; Yerokhin, S. Mountain lakes of Kyrgyzstan with regard to the risk of their rupture. In EGU General Assembly Conference Abstracts, Proceeding of the EGU General Assembly 2009, Vienna, Austria, 19-24 April 2009; European Geosciences Union: Munich, Germany, 2009; EGU2009-14084-1.

21. Keremkulov, V.A.; Tsukerman, I.G. Computations of the outburst flood generated by the emptying of morainic lake through englacial drainage system. Data Glaciol. Stud. 1986, 58, 110-111. (In Russian) 
22. Kapitsa, V.; Shahgedanova, M.; Machguth, H.; Severskiy, I.; Medeu, A. Assessment of evolution and risks of glacier lake outbursts in the Djungarskiy Alatau, Central Asia, using Landsat imagery and glacier bed topography modelling. Nat. Hazards Earth Syst. Sci. 2017, 17, 1837-1856. [CrossRef]

23. Wang, X.; Ding, Y.; Liu, S.; Jiang, L.; Wu, K.; Jiang, Z.; Guo, W. Changes of glacial lakes and implications in Tian Shan, Central Asia, based on remote sensing data from 1990 to 2010. Environ. Res. Lett. 2013, 8, 1-11. [CrossRef]

24. Bolch, T.; Peters, J.; Yegorov, A.; Pradhan, B.; Buchroithner, M.; Blagoveshchensky, V. Identification of otentially dangerous glacial lakes in the northern Tien Shan. Nat. Hazards 2011, 59, 1691-1714. [CrossRef]

25. Tokmagambetov, G.A.; Sudakov, P.A.; Plekhanov, P.A. Glacial mudflows in Zailiysky Alatau (Ile Range) and ways of their prediction. Data Glaciol. Stud. 1982, 43, 63-68. (In Russian)

26. De Batist, M.; Imbo, Y.; Vermeesch, P.M.; Klerkx, J.; Giralt, S.; Delvaux, D.; Lignier, V.; Beck, C.; Kalugin, I.; Abdrakhmatov, K.Y. Bathymetry and sedimentary environments of Lake Issyk-Kul, Kyrgyz Republic (Central Asia): A large, high altitude, tectonic lake. In Lake Issyk-Kul: Its Natural Environment; Klerkx, J., Imanackunov, B., Eds.; Kluwer Academic Publishers: Dordrecht, The Netherlands, 2002; pp. 101-123.

27. Geological Map of the Kyrgyz SSR of 1:500,000 Scale; Academy of Sciences of the Kyrgyz SSR: Bishkek, Kyrgyzstan, 1987; pp. 38-39.

28. Narama, C.; Kääb, A.; Duishonakunov, M.; Abdrakhmatov, K. Spatial variability of recent glacier area changes in the Tien Shan Mountains, Central Asia, using Corona ( 1970), Landsat ( 2000), and ALOS ( 2007) satellite data. Glob. Planet. Chang. 2010, 71, 42-54. [CrossRef]

29. Narama, C.; Shimamura, Y.; Nakayama, D.; Abdrakhmatov, K. Recent changes of glacier coverage in the western Terskey-Alatoo Range, Kyrgyz Republic, using Corona and Landsat. Ann. Glaciol. 2006, 43, $223-229$. [CrossRef]

30. Bolch, T. Climate change and glacier retreat in northern Tien Shan (Kazakhstan/Kyrgyzstan) using remote sensing data. Glob. Planet. Chang. 2007, 56,1-12. [CrossRef]

31. Kutuzov, S.; Shahgedanova, M. Glacier retreat and climatic variability in the eastern Terskey-Alatoo, inner Tien Shan between the middle of the 19 th century and beginning of the 21st century. Glob. Planet. Chang. 2009, 69, 59-70. [CrossRef]

32. Takaku, J.; Tadono, T. PRISM on-orbit geometric calibration and DEM performance. IEEE Trans. Geosci. Remote Sens. 2009, 47, 4060-4073. [CrossRef]

33. Tadono, T.; Kawamoto, S.; Narama, C.; Yamanokuchi, T.; Ukita, J.; Tomiyama, N.; Yabuki, H. Development and validation of new glacial lake inventory in the Bhutan Himalayas using ALOS 'DAICHI'. Glob. Environ. Res. 2012, 16, 31-40.

34. Narama, C.; Daiyrov, M.; Tadono, T.; Yamamoto, M.; Kääb, A.; Morita, R.; Ukita, J. Seasonal drainage of supraglacial lakes on debris-covered glaciers in the Tien Shan Mountains, Central Asia. Geomorphology 2017, 286, 133-142. [CrossRef]

35. Mergili, M.; Müller, J.; Schneider, J.F. Spatio-temporal development of high-mountain lakes in the headwaters of the Amu Darya River (Central Asia). Glob. Planet. Chang. 2013, 107, 13-24. [CrossRef]

36. Sandwell, D.T.; Myer, D.; Mellors, R.; Shimada, M.; Brooks, B.; Foster, J. Accuracy and Resolution of ALOS Interferometry: Vector Deformation Maps of the Father's Day Intrusion at Kilauea. IEEE Trans. Geosci. Remote Sens. 2008, 11, 3524-3534. [CrossRef]

37. Natsuaki, R.; Nagai, H.; Motohka, T.; Ohki, M.; Watanabe, M.; Thapa, R.B.; Tadono, T.; Shimada, M.; Suzuki, S. SAR interferometry using ALOS-2 PALSAR-2 data for the Mw 7.8 Gorkha, Nepal earthquake. Earth Planets Space 2016. [CrossRef]

38. Yamamura, A.; Narama, C.; Tomiyama, N.; Tadono, T.; Yamanokuchi, T.; Daiyrov, M.; Kääb, A.; Ukita, J. Spatial distribution of permafrost in the Kyrgzy Range, Northern Tien Shan using DInSAR analysis for rock glaciers. Permafr. Periglac. Process. submitted.

39. Strozzi, T.; Kääb, A.; Frauenfelder, R. Detecting and quantifying mountain permafrost creep from in situ inventory, space-borne radar interferometry and airborne digital photogrammetry. Int. J. Remote Sens. 2004, 25, 2919-2931. [CrossRef]

40. Lilleøren, K.; Etzelmüller, B.; Gärtner-Roer, I.; Kääb, A.; Westermann, S.; Gudmundsson, A. The Distribution, Thermal Characteristics and Dynamics of Permafrost in Trollaskagi, Northern Iceland, as Inferred from the Distribution of Rock Glaciers and Ice-Cored Moraines. Permafr. Periglac. Process. 2013, 24, 322-335. [CrossRef] 
41. Liu, L.; Millar, C.I.; Westfall, R.D.; Zebker, H.A. Surface motion of active rock glaciers in the Sierra Nevada, California, USA: Inventory and a case study using InSAR. Cryosphere 2013, 7, 1109-1119. [CrossRef]

42. Werner, C.; Wegmüller, U.; Strozzi, T.; Wiesmann, A. Gamma SAR and Interferometric Processing Software. In Proceedings of the ERS-ENVISAT Symposium, Gothenburg, Sweden, 16-20 October 2000.

43. Quincey, D.J.; Richardson, S.D.; Luckman, A.; Lucas, R.M.; Reynolds, J.M.; Hambrey, M.J.; Glasser, N.F. Early recognition of glacial lake hazards in the Himalaya using remote sensing datasets. Glob. Planet. Chang. 2007, 56, 137-152. [CrossRef]

44. Goldstein, R.M.; Werner, C.L. Radar Ice Motion Interferometry. In Proceedings of the 3rd ERS ESA Symposium, ESA SP, Florence, Italy, 14-21 March 1997; pp. 969-972.

45. Kääb, A.; Haeberli, W. Evolution of a High-Mountain Thermokarst Lake in the Swiss Alps. Arct. Antarct. Alp. Res. 2001, 33, 385-390. [CrossRef]

46. Kropáček, J.; Neckel, N.; Tyrna, B.; Holzer, N.; Hovden, A.; Gourmelen, N.; Schneider, C.; Buchroithner, M.; Hochschild, V. Repeated glacial lake outburst flood threatening the oldest Buddhist monastery in north-western Nepal. Nat. Hazards Earth Syst. Sci. 2015, 15, 2425-2437. [CrossRef]

47. Emmer, A.; Vilímek, V.; Zapata, M.L. Hazard mitigation of glacial lake outburst floods in the Cordillera Blanca (Peru): The effectiveness of remedial works. J. Flood Risk Manag. 2016. [CrossRef]

(c) 2018 by the authors. Licensee MDPI, Basel, Switzerland. This article is an open access article distributed under the terms and conditions of the Creative Commons Attribution (CC BY) license (http:/ / creativecommons.org/licenses/by/4.0/). 